\title{
Splitting the Subject: An Overview of Sartre, Lacan and Derrida
}

Sebastian Gardner

University of Cambridge, England

It has been proposed that there is, or that we should assume there to be, such a thing as "a classical conception of the subject," and in the same breath, that we should reject it. This subject has beers conceived as essentially unified, and as substantial. The latter property is now the less defended, and probably the less defensible, and it is therefore on the unity of the subject that "non-classical" expositions of the subject come to focus. My concern here will be to look at various ways in which the subject has been split and to ask on what conditions a truly split subject may be conceived.

Eirst of all I offer a brief, but necessary, resumé of the textual and historical meanderings of my subject.

It is not until Sartre that the Cartesian subject may really be said to have returned froin its experiences at the hands of German idealism. We can, I suggest, see Sartre as attempting in Being and Nothingness to re-perform Descartes' act of self-cognition and, due to centuries' accumulation of self-knowledge, as unable to successfully perform it. It is, hovever, necessary for Sartre that there be an attempt to perform it--its failure does not lead to the desertion of the first-person standpoint. It is the project of conpleting the Cogito that then becomes imperative--the cogito relnains present as if a ghost, figured in the nature of desire.

The reasons for the collapse of the Cogito across time are obviously cnormously complex, but I hope that at least some of the following will be agreed to be of central importance. The attack on rational psychology in Kant's Paralogisms; the restoration of intentionality to consciousness in Brentano and Husserl; the metamorphosis of consciousness into Dasein. Even at this stage of the subject's history, we still have an approximately classical subject. Kant exorcises substratum rather than substance from the subject. Heidegger perhaps only blurs our understanding of the relation between self and consciousness. Insofar as unity suffices for substantiality, a unity of appercep- 
tion or a unity of Sorge is still the unity of a substance." And so it is, I suggest, altogether another set of texts that does the work for sartre: the attention to the fine grain of selfhood in Kierkegaard, Ereud, Nietzsche and Jaspers. It is with the aid of these writers that Sartre undoes the ontological solidity of the subject.

Sartre's dualism is of a special kind and it is one that most brilliantly complements the kind of splitting that Sartre found in Kierkegaardian double-mindedness and in the states of abnormal psychology. crucially. the dualism of Sartre's phenomenological ontology. Crucially, the dualism of Sartre's phenomenological ontology is actually incorporated within the subject, and it is this that puts an end to the security of Descartes" Cogito as an archimedean point. The "I" of the Cogito can no longer appropriate one part of a divided doinain as its uwn. It can no longer identify unequivocally with the realm of the unextended, as a saturated region that it itself truly "is." The mental is in a sense no longer a home.

In this way Sartre can take over Heidegger's language of man's "being outside himself." and in The Transcendence of the Ego he can argue that the self is both an intimate product of the workings of reflexivity and that it is an entirely objective and public content of the world. Sartre's subject is made in selfconsciousness, but it is therein discovered as more worldly than either Descartes or Kant conceived it. The classical subject has by now lost both substance and center.

Being and Nothingness builds up multiple pairs of terms, ranging from basic temporal pairs (present/past, past/future), Hegelian modalities (in-itself/for-itself). contrasts in the language of classical phenomenology (thetic/non-thetic, positional/non-positional). to Sartre's major oppositions of reflective and prereflective and of facticity and transcendence. The text moves around these polarities, assembling, aligning and then disassembling them. Never are they collapsed into one another, and it is by this textual measure ${ }^{2}$ that Sartre is able to grasp. within a coherent theory, the discrepancies within the subject. . So, Sartre has one term of the relation, "manworld," absorb the force of that very contrast and experience it as its own division. Sartre is a Cartesian in denying the positivist thesis that science can elaborate the necessary single concept in terms of which human identity can be represented, and in making reflexivity central; but the Cartesiall Cogito is relegated to the status of a project.

We come now to Lacan. Here, Freud is raised to a fully conceptual plane. If we think of how philosophy 
usually responds to psychoanalytic theory, Lacan's work will appear all the more extraordinary. The orthodox way of "taking" Ereud, in analytic philosophy of mind and in philosophy of science, is something like this: we argue over whether or not a concept of selfhood that has its basis in consciousness can be stretched to cover the unconscious as Freud describes it, and we attempt to see how much mentality can survive the loss of the property "potential object of consciousness." And something not unlike this is, of course, also sartre's proceedure.

How can it be that an empirical theory can effect a juncture with pure thought, and in such a way as to disturb it? The Lacanian answer here will be that ill Freud's texts and in the "psychoanalytic experience" we uncover a split in the subject that is not simply the discovery of new facts describable in the old ways, or merely a new theory for old facts. It aspires to be an event of the order of the Cogito itself, a "philosophical" event, and we must be wary not to misunderstand it.

Before proceeding with Lacan, I digress to produce an argument, in part borrowed from the literature of analytic philosophy, that will point up a highly importent feature of Ereudian metapsychology.

Suppose we begin (I) with the retort that the split in the subject located by freud can not be of philosophical interest, because it is only a division in the multiplcity of belief-states and desire-states of the person or organism, and it therefore can not impinge upon that foundational unity, the Cogito, which is a unity of apperception.

Erom this it would follow that (2) there is a line to be drawn between the person, that can fail of unity, and the cogito or subject. that can not.

Having made this distinction we will be led straight to (3) the undoing of that second element, the subject: we will be led to deny, when we think about conditions of identity, that there can be any reference to an entity that can only preserve its unity by parting coinpany with an empirical self whose nature is then yielded up to the natural sciences.

Let us take another look at what happens in this positivist line of thought. We are left with a psychoanalytically describable entity, one for which we can construct psychic topographies, but one without anything truly recognizable as internal division. 'lo explain, in pressing home the split in the subject, we eliminated the Cogito. But this left us with only a system of belief-states and desire-states capable of various degrees of integration and disintegration. We can mo longer raise the question of reflexive unity-that unity I "take myself to have"--and we can no longer predicate it or its contrary of the peisun. 

Freudian psychology melts into functionalist theory of
the mind.

The arguments that complete this "elimination of consciousness" derive in part from analytic philogophy's readings of the Philosophical Investigations and in part from theoretical reflection on cognitive science.' Its relevance to Lacan lies in its showiug just how precarious consciousness becomes in any theory that starts from features of the subject's internal division. I will later hint at an analogy between a world of material states and a world of signs, and suggest that the above could be rewritten substituting 'signifier' for 'mental state'.

Consciousness, let alone self-consclousness, has in psychoanalysis always been on the verge of shrinking to mere perceptual registration, and thus constituted an embarassment for Freud himself, whose remarks on the question are highly contradictory. ${ }^{4}$ I suggest that in restoring the unconscious to its rightful place and in overturning ego-psychology, the shallow Anglo-American psychoanalysts ' readings of Ereud, Lacan has had to fall prey to this danger, and can not prevent the divided subject from being absorbed back into nature and thereby regaining a sort of wholeness. This result is perhaps less surprising when we recall how much structuralism there is in Lacan and the drive in structuralism to "translate culture back into nature."

- To elaborate Lacan further we must, at least for purposes of presentation, turn to Derrida. The reason for this is that the meaning of the Saussurean "split" $\mathrm{S} / \mathrm{s}$, which is the split elided by Lacan with the Freudian division, is only clearly developed in Derrida. This should not be taken to imply that there is only agreement between Lacan and Derrida; it is only to say that I do not find enough in Lacan's texts to make his use of $S / s$ comprehensible without thinking of it as sufficiently sinilar to differance itself so as to be elaborated by it.

In his critique of Husserl." Derrida argues firstly against unmediated self-knowledge, and secondly from the nature of the sign to the nature of the mediation. The role of $\mathrm{s} / \mathrm{s}$ comes in the second part of the argument--if something arbitrary, in the special differential sense, effects self-knowledge, then selfknowledge becomes something very hard to conceive. At least, we can no longer claim to fill the concept of self-knowledge with our experience of self-presence. And we are challenged to show how we understand it at all.

I restate the argument: requires self-representation and is (1) self-knowledge by self-presence: (2) there is then not made possible within the constraints of representation and representation is infected by S/s/differance; (3) the subject's 
self-representation is especially "weak," for the subject is bound up in representation in a way that other items in the world can not be. As with sartre, the subject comes out as the least solid of all things'--a kind of inverted privilege.

Returning to Lacan, the split in the bar of $S / s$ is used to genelate the various divisions of Cs./Ucs.. self-other, self/other, the knot of the Oedipal complex, and the patterns of "choice" ("money-or-youriife (if) that underlie desire and its distinctness from demand. In short, psychoanalytic theory is reformulated in terms of differance.

What is of great interest, when we reflect on how and where splits have been inserted in the subject, is the way in which the formal subject-elininating argument I gave above has been as if enacted by the compound of Lacan-Derrida. In the second stage of that argument (2), experiential subject and psychic individual were divided: which is of course what happens when Lacan deploys the $\mathrm{s} / \mathrm{s}$ to effect the division between consciousness and unconsciousness, Cs. and Ucs. In the third stage (3), one of these terms was abolished. And it is precisely in Derrida's analysis of the subject of the phenomenologists that this is repeated--we are driven to renounce the subject altogether. One application of the $\$ / s$ separates subjectivity from the self; another eliminates that residual subjectivity altogether.

And so, I contend, to re-examine the Lacanian split in the subject is to find it dependent on a Derridaean "metaphysic," and it is therefore to require the iteration of $S / s$, and the elimination of subjectivity. The attack on the classical subject yields not a split subject, but no subject at all. Ironically, the dissolution of the subject leaves us with precisely that conception of the person employed in analytic philosophy of mind.

The texts of Lacan-Derrida must therefore retain enough of the Cogito to prevent such a slide. And both are aware of this; but whether they have any right to retain any of the Cogito is sotnething I hope to have made dubious.

Derrida's "position" is, as it should be, hard to make out. On the one hand we have the explicit statements that there "is no perception," and in Speech and Phenomena the argument that without presence, we simply have no notion of consciousness. Yet in writing less expository texts, on madness and the cogito, the cogito is accorded notional supremacy and monopoly on Reason, and eroded in more strategic manner."

Lacan's double-game on this matter can be illustrated by a little stylistic analysis. If we examine, "I am not, wherever I am the playing of my thought," we find a rhetoric that procures identification of the reader with the cogito, and effectively encourages it-. 
in order to then break it. As I read, I lose selfidentity: from being identified with the first instance of "I," I am forced to then choose between giving up my identity with "my thought," or the identity of myself with thought (presence). The Lacanian thesis, or experience, clearly exploits the lingering presence of the Cogito, and the coherence of his thought requires the paradoxical form. The Cogito must continue as the "Outside" of Lacan's texts, as that with which psychoanalysis is confronted, in order that the oppositious within psychoanalysis should produce a split subject, and not merely formal disintegrities of a system.

We recall that Sartre viewed Ereud as a theorist wholly in error, and even as laying the foundations for mauvaise foi. We may also note Sartre's absence from the discussions of the subject in present literature. to the point where his presence seems to undergo repression.

What relations are we to say hold between the three splits in subjectivity that I have isolated here-the Sartrean division, focussed on self-deception; the Freudian, issuing from unconscious motivation (and identified in Lacan with the third); and the Derridean, glossed here as the "bar" in the sign. It can be argued, I think, that the first two can be superimposed, but that this requires us to abandon the third, that is, not read Freud as Lacan does. And here I wish to end by pruposing something similar.

I suggest that when we reread Sartre, after the interval of Lacan and Derrida, we find a solution to the contradiction that we uncoverod in the latters' writings. The following four features of Sartre's theory seem to me derisive:

(1) Sartre provides a critique of the substantial conception of the unconscious on a par with Kant's critique of substantial selfhood. 'l'his gives us all we need to deny the duplication of the cogito at a second level; Lacan's insistence on the uncunsaious as other is superfluous (although I an glad to concede that it was necessary for Lacan to find some means of countering extant readings of Freud, with a richer conceptual apparatus).

(2) Sartre works out the senses in which the unconscious makes problematic consciousness in terms of facticity and transcendence, and thereby in terms of the failure and incompleteness of reflexivity. It is then an account which tells us how it is that the cogito fails in a way that makes that failure available for consciousness (so that I can say. "I fail of selfknowledge").

(3) The concepts of lack and nothingness do all that is done by talk of other and of the other in lacan, so that sartre has as fully intersubjective an 
account as could be required, and is not condemned to the problem of explaining how a solipsistic consciousness could be split (as Husserl and perhaps MerleauPonty would be, had they broached the question).

(4) Derrida's critique of Husserlian self-presence is, in all essentials, already achieved in Sartre's The Transcendence of the Ego, in the treatment of the relation between thetic and non-thetic and reflective and non-reflective consciousness. Sartre there shows how reflectivity can secure a ininimal, impoversihed selfpresence, from which self-knowledge proper is still at a great distance. No Illusions of self-access are grounded.

In conclusion, we found that the attack on the classical subject, the Cogito, could be takell to such a point that its elimination yielded a re-unified entity--the person, an organism and object of empirical science, or the self-as-text, an expanse of signs. In this there was a transition from substantial unity to the unity of a system. In both the positivist order of physical facts, and the Derridean disorder of textuality, the forsaking of consciousness involves a sacrifice of that tension which is required for what $I$ have called a spilt subject. Both worlds are curiously flat, monotonous, inanimate.

And so the choice as I see it lies between accepting an intact and undivided cogito haunting a divided person, as we have in effect in Lacan; and rediscovering Sartre to find all of the splits of selfhood contained within a complexified and split cogito. I hope to have justified a preference for the latter, and thereby for according an oblique and qualified primacy to intertionality over signification. $10^{2}$

\section{NOTES}

'Does unity suffice for substantiality? The argument here is that, outside the framework of transcendental idealism, we can only get a non-substantial unity by splitting the subject itself, and not by working from the arbitrary nature of the sign.

${ }^{2}$ This is perhaps a deconstructive virtue of the text. In any case, it saves Sartre from the charge of having re-essentialised man by assigning to him a "passion inutile" with unitary content.

\footnotetext{
'See W. Sellars in ed. Lambert, "l'he Logical Way of Doing Things," Anscombe, "The First Person," $S$.
} 

Shoemaker, "Self-Knowledge and Self-Identity." P.
Kitcher in PR 1982.

"Compare consciousness in the 1915 paper "The Unconscious," with remarks in New Introductory Lectures.

"Levi-Strauss, "The Savage Minds."

'Speech and Phenomena.

'Perhaps less capable of self-reference than are literary texts, that can at least refer to themselves on a single metonymic axis by the trope of synechdoche.

"This must be qualified with the recognition that in "Freud and the Scene of Writing," Derrida does display an acute consciousness of the problem at hand, and sees it as propelling Ereud's search for the "right" metaphor.

"In a Ms, "Psychoanalysis and Self-Deception," I try to argue that this is possible, on the condition that we regard states of the Ucs. as "Unowned."

:I would like to thank John and Cindy willettshoptaw and all others in Harvard's literary theory group for understanding and encouragement. 